\title{
Seroprevalence rates of antibodies against Leishmania infantum and other protozoan and rickettsial parasites in dogs
}

Soroprevalência de anticorpos contra Leishmania infantum e outras espécies de protozoários e rickettsia em cães

Silvana de Cássia Paulan ${ }^{1}$; Aline Gouveia de Souza Lins²; Michely da Silva Tenórioº; Diogo Tiago da Silva²; Hilda Fátima de Jesus Pena4; Rosangela Zacarias Machado5; Solange Maria Gennari;

Wilma Aparecida Starke Buzetti ${ }^{2 *}$

\begin{abstract}
${ }^{1}$ Departamento de Apoio, Produção e Saúde Animal, Faculdade de Medicina Veterinária, Universidade Estadual Paulista - UNESP, Araçatuba, SP, Brasil

${ }^{2}$ Departamento de Biologia e Zootecnia, Faculdade de Engenharia, Universidade Estadual Paulista - UNESP, Ilha Solteira, SP, Brasil

${ }^{3}$ Departamento de Microbiologia e Imunologia, Instituto de Biociências, Universidade Estadual Paulista - UNESP, Botucatu, SP, Brasil

${ }^{4}$ Departamento de Medicina Veterinária e Saúde Animal, Faculdade de Medicina Veterinária e Zootecnia, Universidade de São Paulo - USP, São Paulo, SP, Brasil
\end{abstract}

${ }^{5}$ Departamento de Patologia Veterinária, Faculdade de Ciências Agrárias e Veterinárias, Universidade Estadual Paulista - UNESP,

Jaboticabal, SP, Brasil

Received February 16, 2012

Accepted October 4, 2012

\begin{abstract}
Canine visceral leishmaniasis (CVL) is caused by the protozoan Leishmania infantum, which infects dogs and humans in many regions of Brazil. The present study involved an indirect fluorescent antibody test (IFAT) to analyze L. infantum, Ehrlichia spp., Babesia canis, Toxoplasma gondii and Neospora caninum infection rates in serum samples from 93 dogs in a rural settlement in Ilha Solteira, SP, Brazil. The seroprevalence rates of anti-L. infantum, anti-Ehrlichia, anti-B. canis, anti-T. gondii and anti- $N$. caninum antibodies were $37.6 \%, 75.3 \%, 72 \%, 47.3 \%$ and $6.4 \%$, respectively. In addition to IFAT, direct microscopic examination of popliteal lymph node aspirates revealed $26.9 \%$ of CVL positive dogs. Serological tests revealed that $17.2 \%$ of the dogs were seropositive for a single parasite, $29 \%$ for two parasites, $33 \%$ for three, $16.1 \%$ for four, and $1.1 \%$ for five parasites, while $3.2 \%$ were seronegative for five parasites. The presence of antibodies against these parasites in serum samples from dogs confirmed their exposure to these parasites in this rural area. Because of the potential zoonotic risk of these diseases, mainly leishmaniasis, ehrlichiosis and toxoplasmosis, special attention should focus on programs for the improvement of diagnostic assays and control measures against these parasites.
\end{abstract}

Keywords: Leishmania, Babesia, Ehrlichia, Toxoplasma, Neospora, dogs.

\section{Resumo}

Leishmaniose Visceral Canina (LVC) é causada pelo protozoário Leishmania infantum, podendo infectar cães e humanos em várias regiōes do Brasil. O presente estudo teve por objetivo realizar a reação de imunofluorescência indireta (RIFI) para analisar os índices de infecção parasitária para L. infantum, Ehrlichia spp., Babesia canis, Toxoplasma gondii e Neospora caninum, em 93 amostras de soro de cáes de um assentamento rural no município de Ilha Solteira, SP, Brasil. A taxa de soroprevalência de cáes com anticorpos anti-L. infantum, anti-Ehrlichia, anti-B. canis, anti-T. gondii e anti- $N$. caninum foi de 37,6\%,75,3\%,72\%, 47,3\% e 6,4\%, respectivamente. Pelo exame microscópico direto dos parasitas nos esfregaços de aspirados de linfonodos poplíteos dos cães, a positividade para LVC foi de $26,9 \%$. Pelos exames sorológicos, $17,2 \%$ dos cáes estavam positivos com um único parasita, $29 \%$ com dois, $33 \%$ com três, $16,1 \%$ com quatro e 1,1\% com cinco parasitas. Além disso, 3,2\% eram soronegativos para todos os cinco agentes parasitários. A presença de anticorpos aos parasitos em amostras sorológicas confirmam a exposição dos cáes às doenças parasitárias nesse assentamento rural. Devido ao potencial risco zoonótico destas doenças, principalmente leishmaniose, erliquiose e toxoplasmose, atenção especial deve ser dada aos programas que objetivam o aprimoramento de testes diagnósticos e de medidas de controle dessas parasitoses.

Palavras chave: Leishmania, Ehrlichia, Babesia, Toxoplasma, Neospora, cães.

\footnotetext{
${ }^{*}$ Corresponding author: Wilma Aparecida Starke Buzetti

Departamento de Biologia e Zootecnia, Faculdade de Engenharia,

Universidade Estadual Paulista - UNESP, Av. Brasil, 56, CEP 15385-000,

Ilha Solteira, SP, Brasil

e-mail: starke@bio.feis.unesp.br
} 
Canine Visceral Leishmaniasis (CVL) is a disease caused by a kinetoplastid protozoan of the genus Leishmania (ROSS, 1903). Leishmania infantum (syn. L. chagasi) is the causative agent of visceral leishmaniasis in the New World, with endemic regions extending from southern USA to northern Argentina, including Brazil (KUHLS et al., 2011), which is transmitted to humans and animals by the bite of the sandfly Lutzomyia longipalpis (Diptera: Psychodidae: Phlebotominae) (PORROZZI et al., 2006). The main factors that favor the evolution and dissemination of CVL are human invasion of natural endemic areas; migration from rural to urban areas, and social and economic deterioration, particularly in suburban areas (DESJEUX, 2004; GRAMICCIA; GRADONI, 2005; ALVAR et al., 2006).

Dogs can be infected naturally by a variety of parasites of wide geographical distribution (GUIMARÁES et al., 2009). Toxoplasma gondii is a protozoan that infects humans and wild and domestic animals worldwide, including domestic dogs (SOUZA et al., 2003; AZEVEDO et al., 2005; DUBEY et al., 2007; LOPES et al., 2011). Neospora caninum is an intracellular protozoan causing a serious disease in cattle and dogs worldwide (DUBEY et al., 1988). Recent Brazilian surveys of foxes found seropositivity for $N$. caninum, T. gondii and L. infantum in 3.2\%, 18.0\% and 78.1\%, respectively (CATENACCI et al., 2009). Coinfection has already been described with L. infantum and N. caninum (TARANTINO et al., 2001; CRINGOLI et al., 2002; ANDREOTTI et al., 2006) and with these parasites and T. gondii in dogs (GENNARI et al., 2006; RIBEIRO et al., 2011). In addition, some studies suggest that immunosuppression caused by Leishmania spp. can enhance the susceptibility of dogs to coccidian parasites (CRINGOLI et al., 2002; GENNARI et al., 2006).

Babesiosis and Ehrlichiosis are tick-borne diseases that are very common in dogs, the former caused by an intraerythrocytic parasite, Babesia canis (LOBETTI, 1998), and the latter by an obligate intracytoplasmic rickettsia, Ehrlichia spp. (GUILLÉN LLERA et al., 2002). Some studies have reported cross-reaction between Leishmania and E. canis or Leishmania and B. canis in serological tests (GOMES; CORDEIRO, 2004). However, Oliveira et al. (2008) examined serum samples from dogs living in indemic and non-endemic areas for CVL and found only coinfection, but not antibody cross-reaction between anti-Leishmania and anti-B. canis or anti-Leishmania and anti-E. canis.

The purpose of this study, therefore, was to analyze the seroprevalence rates of antibodies against L. infantum, Ehrlichia spp., $B$. canis, $T$. gondii and $N$. caninum in serum samples from dogs living in a rural settlement in an area where CVL is endemic.

This rural settlement of about three thousand hectares is located in the municipality of Ilha Solteira, São Paulo, Brazil $\left(20^{\circ} 25^{\prime} 36.47^{\prime \prime} \mathrm{S}\right.$ and $\left.51^{\circ} 20^{\prime} 26.47^{\prime \prime} \mathrm{W}\right)$ close to an urban area, and is divided into small land holdings of about 14 ha each, where about 209 families live. An estimated 600 dogs live in this settlement.

This study involved dogs $(\mathrm{n}=93)$ of different breeds and ages (from 5 months to 18 years old) and both sexes from this rural settlement. Serum samples were collected from these dogs and subjected to an indirect fluorescent antibody test (IFAT) to detect antibodies against four protozoan and one rickettsial parasite. The study was approved by the Animal Ethics Committee of UNESP at Jaboticabal, under Protocol no. 010208.
To detect anti-L. infantum antibodies, the IFAT was performed according to Oliveira et al. (2008) and is briefly described below.

Leishmania parasites were obtained from bone marrow of naturally infected dogs and maintained in RPMI-1640 medium at $25^{\circ} \mathrm{C}$. Promastigotes of Leishmania maintained in culture medium were placed on slides and used as antigen for the IFAT procedure. Double serum dilutions starting at 1:40 (cutoff point) were placed on the antigens, followed by incubation at $37^{\circ} \mathrm{C}$ for 30 minutes. The slides were then incubated with anti-dog IgG serum conjugated with fluorescein isothiocyanate (KPL, USA) diluted at 1:30 in PBS containing 1\% of Evans Blue and washed in PBS. After adding buffered glycerin, the slides were examined under a fluorescent microscope. Reference sera were included as negative and positive controls. Samples that displayed a bright-green peripheral stain with a dull fluorescence of the parasite cytoplasm were considered positive.

IFAT for B. canis was performed as described by Furuta et al. (2009), and serum samples were positive starting at dilutions of 1:40 and higher. E. canis IFAT was performed using IFAT test kits according to the manufacturer's instructions (VMRD Inc., USA), and serum samples tested at a dilution of 1:40 were considered positive.

Tachyzoites were used as antigen for anti- $T$. gondii antibodies (RH strain), as described by Camargo (1974). For anti-N. caninum antibody detection, IFAT was performed using culture-derived NC-1 isolate tachyzoites (DUBEY et al., 1988). Rabbit anti-canine IgG conjugate (Sigma, USA) was used in both tests and sera were tested in 2-fold serial dilutions, starting at 1:16 for $T$. gondii and 1:50 (cutoff point) for $N$. caninum. Positive and negative control sera were added to all the reactions.

The presence of amastigote forms of Leishmania was examined under a light microscope (1000x magnification) in smears of popliteal lymph node aspirates fixed in methanol and stained with Giemsa.

For statistical analyses, the chi-square test with a significance level of $5 \%$ was performed using BioEstat ${ }^{\oplus} 5.0$ software to assess the associations between the presence of antibodies against Ehrlichia spp., B. canis, T. gondii and N. caninum in L. infantum positive and negative dogs.

Ilha Solteira is a municipality well known to be endemic for CVL (NORONHA JUNIOR et al., 2007; ASSIS et al., 2010; QUEIROZ et al., 2010), where the prevalence rate of CVL in dogs living in urban areas is reportedly 23\% (NORONHA JUNIOR et al., 2007).

This paper reports the occurrence of CVL in a rural settlement in the municipality of Ilha Solteira, located close to an urban area (southeastern Brazil). Thirty-five of the 93 dogs (37.6\%) were positive in serological tests (Table 1) and 25 out of $93(26.9 \%)$ in parasitological tests. In addition, the IFAT indicated that $17.1 \%$ of the dogs showed high levels of antibodies (titer $\geq 1280$ ). This prevalence rate was lower than that observed by Queiroz et al. (2010) in urban areas of the same municipality (55.9\%), but the occurrence of the disease represents a risk in both rural and urban areas because the presence of $L$. longipalpis that contributes for parasite dispersion (PAULAN et al., 2012). Four percent of these CVL positive dogs were symptomatic and the most frequent clinical signs were weight loss, onycogryphosis, hypertrophic popliteal lymph nodes, alopecia and other dermatological alterations. 
Table 1. Antibody detection of Leishmania infantum, Ehrlichia spp., Babesia canis, Toxoplasma gondii and Neospora caninum in serum samples of 93 dogs from a rural settlement, Ilha Solteira, SP, Brazil, by IFAT.

\begin{tabular}{cccc}
\hline \multirow{2}{*}{ Parasites } & \multicolumn{3}{c}{$\begin{array}{c}\text { Numbers and percentages of serum positive } \\
\text { dogs by IFAT }\end{array}$} \\
\cline { 2 - 3 } & \multicolumn{3}{c}{ Positive } \\
\cline { 2 - 3 } IFAT(cut-off) \\
\hline L. infantum & 35 & 37.6 & $1: 40$ \\
Ehrlichia spp. & 70 & 75.3 & $1: 40$ \\
B. canis & 67 & 72.0 & $1: 40$ \\
T. gondii & 44 & 06.5 & $1: 50$ \\
N. caninum & 06 & 47.3 & $1: 16$ \\
\hline
\end{tabular}

$\mathrm{N}^{\circ}$ - number; \% percentage.

In addition to $L$. infantum, dogs had antibodies reactive to multiple parasites, including other protozoans (B. canis, T. gondii and $N$. caninum) and rickettsial (Ehrlichia spp.) parasites (Table 1). In this study, $95.7 \%$ of the dogs $(89 / 93)$ had serum reactive to 1 to 5 parasites: $4.3 \%, 17.2 \%, 28 \%, 33.3 \%, 16.1 \%$ and $1.1 \%$ of the dogs with antibodies targeted to zero, one, two, three, four and five parasites, respectively, which was indicative of coinfections. In addition, $13.8 \%, 8.6 \%$ and $5.7 \%$ of the dogs were serum positive for only one parasite, as follow: Ehrlichia, Babesia and Leishmania, respectively. However, one dog (1.1\%) had serum reactive to five parasites, and most of the dogs (61.3\%) showed antibody reactivity from 2 to 3 parasites with the following associations: Leishmania $\times$ Babesia $\times$ Toxoplasma or Leishmania $\times$ Ehrlichia $\times$ Toxoplasma $(48.6 \%)$ or Leishmania $\times$ Babesia $\times$ Ehrlichia $(31.4 \%)$. The association between two parasites ranged from $62.9 \%$ to $74.3 \%$ (Table 2 ).

For hemoparasites, $75.3 \%$ and $72 \%$ of the dogs were serum positive for Ehrlichia spp. and B. canis, respectively, which represented the most prevalent parasites (Table 1). Similarly high prevalence rates of $B$. canis (OLIVEIRA et al., 2008; FURUTA et al., 2009) and Ehrlichia spp. (OLIVEIRA et al., 2008) were reported in dogs from urban areas in Brazil. It is well known that both parasites (Ehrlichia spp. and B. canis) are transmitted by the brown dog tick Rhipicephalus sanguineus in endemic areas in Brazil (LABRUNA; PEREIRA, 2001; DANTAS-TORRES, 2008). The dogs in this rural settlement were frequently infected with these ticks, which explains the high prevalence of these hemoparasites.

Serum antibody reactivity was also detected simultaneously for $L$. infantum $\times$ Ehrlichia spp. or L. infantum $\times B$. canis in $74.3 \%$ of the dogs, for B. canis $\times$ Ehrlichia spp. in $50 \%$, and for L. infantum $\times$ B. canis $\times$ Ehrlichia spp. in $31.4 \%$. We agree with Oliveira et al. (2008) that the high prevalence rates of these two hemoparasites in a CVL endemic area is much more suggestive of coinfections than of antibody cross reaction among these three parasites.

T. gondii and $N$. caninum are two coccids that are important for animal and human public health (DUBEY et al., 1988). In the present study (southeastern Brazil), $47.3 \%$ of the dogs from a rural area were positive for the presence of anti- $T$. gondii (Table 1 ), with antibody titers ranging from 16 to 2048 . In contrast, the prevalence rate of T. gondii based on serological tests in dogs living in urban areas of northeastern Brazil was only 18\% (LOPES et al., 2011).
Table 2. Antibody positivity against Leishmania infantum (L); Ehrlichia spp. (E); Babesia canis (B); Toxoplasma gondii (T) and Neospora caninum (N) in different parasitic associations in serum samples from dogs in a rural settlement in Ilha Solteira, SP, Brazil.

\begin{tabular}{ccc}
\hline \multirow{2}{*}{$\begin{array}{c}\text { Parasite } \\
\text { association }\end{array}$} & \multicolumn{2}{c}{$\begin{array}{c}\text { Leishmania positive dogs } \\
(\mathbf{N}=35)\end{array}$} \\
\cline { 2 - 3 } $\mathrm{L} \times \mathrm{B} \times \mathrm{E} \times \mathrm{T} \times \mathrm{N}$ & No. & 02.9 \\
$\mathrm{~L} \times \mathrm{B} \times \mathrm{E} \times \mathrm{T}$ & 13 & 37.1 \\
$\mathrm{~L} \times \mathrm{B} \times \mathrm{E}$ & 11 & 31.4 \\
$\mathrm{~L} \times \mathrm{B} \times \mathrm{T}$ & 17 & 48.6 \\
$\mathrm{~L} \times \mathrm{B} \times \mathrm{N}$ & 01 & 02.9 \\
$\mathrm{~L} \times \mathrm{B} \times \mathrm{E} \times \mathrm{N}$ & 02 & 05.7 \\
$\mathrm{~L} \times \mathrm{B} \times \mathrm{T} \times \mathrm{N}$ & 00 & 00.0 \\
$\mathrm{~L} \times \mathrm{E} \times \mathrm{T} \times \mathrm{N}$ & 00 & 00.0 \\
$\mathrm{~L} \times \mathrm{T} \times \mathrm{N}$ & 01 & 02.9 \\
$\mathrm{~L} \times \mathrm{E} \times \mathrm{N}$ & 01 & 02.9 \\
$\mathrm{~L} \times \mathrm{E} \times \mathrm{T}$ & 17 & 48.6 \\
$\mathrm{~L} \times \mathrm{B}$ & 26 & 74.3 \\
$\mathrm{~L} \times \mathrm{E}$ & 26 & 74.3 \\
$\mathrm{~L} \times \mathrm{T}$ & 22 & 62.9 \\
$\mathrm{~L} \times \mathrm{N}$ & 02 & 05.7 \\
$\mathrm{~L}$ & 02 & 05.7 \\
\hline
\end{tabular}

No - number; \% percentage.

Dogs are considered sentinels for $T$. gondii environmental contamination, and the high prevalence of this parasite in dogs in this rural settlement demonstrates its wide distribution in that region. The owners of these dogs allowed them to roam outside home, which presumably placed them in closer contact with other sources of animal products and higher exposure to $T$. gondii oocysts from cats roaming freely in the area. It is well known that the presence of cats and their close contact with dogs are important factors in the epidemiology of the disease (DUBEY; BEATTIE, 1988). Thus, the presence of cats in this rural settlement may have favored the dispersion of oocysts and increased the risk of environmental contamination.

In contrast, these dogs showed a very low seroprevalence of anti- $N$. caninum antibody, which reached only $6.5 \%$ (Table 1 ), with antibody titers from 100 to 6400. Azevedo et al. (2005) reported a similarly low seroprevalence in dogs in northeastern Brazil (8.4\%), which was much lower than that reported by Gennari et al. (2002) for dogs in the city of São Paulo, SP (18\%) and by Souza et al. (2002) for dogs in a rural area in the state of Paraná (21.6\%). In fact, this low prevalence was surprising due to the presence of cattle on most of the properties in the rural settlement, which could contribute to increase the risk of transmission of neosporosis; however, there was no data about Neospora infection in cattle in that area.

Simultaneous seroreactivity was also detected against Leishmania and coccidial parasites (Toxoplasma and Neospora) in addition to Ehrlichia and Babesia in different degrees of association (Table 2) suggestive of coinfection, which require further studies.

Some protozoan parasites are known to be immunosuppressive and may predispose the host to the invasion and proliferation of 
Table 3. Occurrence in numbers $\left(\mathrm{N}^{\circ}\right)$ and percentages $(\%)$ of anti $B$. canis, anti-Ehrlichia spp., anti-T. gondii and anti-N. caninum antibodies in positive $(+)$ and negative $(-)$ dogs for Leishmania infantum, by IFAT and parasitological tests in a rural settlement, Ilha Solteira, SP, Brazil.

\begin{tabular}{cccccc}
\hline \multirow{2}{*}{ Parasites } & & \multicolumn{2}{c}{$\begin{array}{c}\text { Leishmania positive } \\
\text { dogs }(\mathbf{N}=35)\end{array}$} & \multicolumn{2}{c}{$\begin{array}{c}\text { Leishmania } \\
\text { dogs }(\mathbf{N}=\mathbf{5 8})\end{array}$} \\
\cline { 2 - 6 } & & No & \% & No & $\%$ \\
\hline Ehrlichia & $(+)$ & 26 & 74.3 & 44 & 75.8 \\
& $(-)$ & 09 & 25.7 & 14 & 24.1 \\
B. canis & $(+)$ & 26 & 74.3 & 41 & 70.7 \\
& $(-)$ & 09 & 25.7 & 17 & 29.3 \\
T. gondii & $(+)$ & $22 *$ & 62.9 & 22 & 37.9 \\
& $(-)$ & 13 & 37.1 & 36 & 62.1 \\
N. caninum & $(+)$ & 02 & 5.7 & 04 & 6.9 \\
& $(-)$ & 33 & 94.3 & 54 & 93.1 \\
\hline
\end{tabular}

*Statiscally significant association $\left(\mathrm{X}^{2}=6.47 ; \mathrm{p}=0.01\right)$ between parasite infection $\left(\mathrm{L}^{+} \times \mathrm{T}^{+}\right)$. $\mathrm{N}^{\circ}$ - number; \% percentage.

other concomitant parasites or bacteria (PINELLI et al., 1994). Although antibody reactivity between $L$. infantum and other parasites was observed (Table 3), a significant association was observed only between L. infantum and T. gondii $\left(\mathrm{X}^{2}=6.47 ; \mathrm{p}=0.01\right)$, suggesting immunosuppression caused by Leishmania spp., which could enhance the susceptibility of dogs to coccidian parasites. However, this hypothesis lacks scientific corroboration. In contrast, no statistically significant parasitic association was detected between L. infantum and B. canis or N. caninum and E. canis (Table 3). This is consistent with studies of $N$. caninum (GRECA et al., 2010; ANDREOTTI et al., 2006) that revealed no parasitic association as well as correlation in dogs naturally infected with Leishmania spp. Nevertheless, it is important to emphasize that these positive dogs for T. gondii and Leishmania shared the same habitat marked by poor sanitary conditions, the presence of sand flies, coccidian oocysts, ticks and animals positive for different parasitic diseases, and were therefore equally exposed to many risk factors for the infection.

In conclusion, this study reports the occurrence of antibody seroreactivity against L. infantum, Ehrlichia spp., B. canis, T. gondii and $N$. caninum in dogs from a rural settlement in Ilha Solteira, SP, Brazil. The dogs had antibodies targeting simultaneously for two to five of these parasites, suggesting coinfections in different degrees of parasitic association. Due to the zoonotic potential of the canine diseases caused by these parasites, particularly leishmaniasis, ehrlichiosis and toxoplasmosis, special attention should focus on improving diagnostic assays and on implementing adequate control measures.

\section{Acknowledgements}

The authors thank the São Paulo State Research Funding Agency - FAPESP for its financial support of this work.

\section{References}

Alvar J, Yactayo S, Bern C. Leishmaniasis and poverty. Trends Parasitol 2006; 22(12):552-557. PMid:17023215. http://dx.doi. org/10.1016/j.pt.2006.09.004

Andreotti R, Oliveira JM, Silva EA, Oshiro LM, Matos MF. Occurrence of Neospora caninum in dogs and its correlation with visceral leishmaniasis in the urban area of Campo Grande, Mato Grosso do Sul, Brazil. Vet Parasitol 2006; 135(3-4): 375-379. PMid:16310954. http://dx.doi. org/10.1016/j.vetpar.2005.10.011

Assis J, Queiroz NMGP, Silveira RCV, Nunes CM, Oliveira TMFS, Noronha Junior ACF, et al. Comparative study of diagnostic methods for visceral leishmaniasis in dogs from Ilha Solteira, SP. Rev Bras Parasitol Vet 2010; 19(1): 17-25. PMid:20385055. http://dx.doi.org/10.4322/ rbpv.01901004

Azevedo SS, Batista CSA, Vasconcellos SA, Aguiar DM, Ragozo AMA, Rodrigues AAR, et al. Seroepidemiology of Toxoplasma gondii and Neospora caninum in dogs from the state of Paraíba, northeast region of Brazil. Res Vet Sci 2005; 79(1): 51-56. PMid:15894024. http://dx.doi. org/10.1016/j.rvsc.2004.10.001

Camargo ME. Introdução às técnicas de imunofluorência. Rev Bras Patol Clin 1974; 10(4): 143-171.

Catenacci LS, Griese J, Silva RC, Langoni L. Toxoplasma gondii and Leishmania spp. infection in captive crab-eating foxes, Cerdocyon thous (Carnivora, Canidae) from Brazil. Vet Parasitol 2009; 169(1-2): 190-192. PMid:20060648. http://dx.doi.org/10.1016/j.vetpar.2009.12.019

Cringoli G, Rinaldi L, Capuano F, Baldi L, Veneziano V, Capellli G. Serological survey of Neospora caninum and Leishmania infantum co-infection in dogs. Vet Parasitol 2002; 106(4): 307-313. http://dx.doi. org/10.1016/S0304-4017(02)00114-0

Dantas-Torres F. Canine vector-borne diseases in Brazil. Parasit Vectors 2008; 1(1): 25. PMid:18691408 PMCid:2533296. http://dx.doi. org/10.1186/1756-3305-1-25

Desjeux P. Leishmaniasis: current situation and new perspectives. Comp Immunol Microbiol Infect Dis 2004; 27(5): 305-318. PMid:15225981. http://dx.doi.org/10.1016/j.cimid.2004.03.004

Dubey JP, Gennari SM, Sundar N, Vianna MC, Bandini LM, Yai LE, et al. Diverse and atypical genotypes identified in Toxoplasma gondii from dogs in São Paulo, Brazil. J Parasitol 2007; 93(1): 60-64. PMid:17436942. http://dx.doi.org/10.1645/GE-972R.1

Dubey JP, Beattie CP. Toxoplasmosis of Animals and Man. Boca Raton: CRC Press; 1988.

Dubey JP, Carpenter JL, Speer CA, Topper MJ, Uggla A. Newly recognized fatal protozoan disease of dogs. J Am Vet Med Assoc 1988; 192(9): 1269-1285. PMid:3391851.

Furuta PI, Oliveira TMFS, Teixeira MCA, Rocha AG, Machado RZ, Tinucci-Costa M. Comparison between a soluble antigen-based ELISA and IFAT in detecting antibodies against Babesia canis in dogs. Rev Bras Parasitol Vet 2009; 18(3): 41-45. PMid:19772774. http://dx.doi. org/10.4322/rbpv.01803007

Gennari SM, Nañon-Franco WA, Feitosa MM. Presence of anti-Neospora caninum and Toxoplasma gondii antibodies in dogs with visceral leishmaniasis from the region of Araçatuba, São Paulo, Brazil. BrazJ Vet Res Anim Sci 2006; 43(5): 613-619. 
Gennari SM, Yai LEO, D’Auria SNR, Cardoso SMS, Kwok OCH, Jenkins MC, et al. Occurrence of Neospora caninum antibodies in sera from dogs of the city of São Paulo, Brazil. Vet Parasitol 2002; 106(2): 177-179. http://dx.doi.org/10.1016/S0304-4017(02)00052-3

Gomes APS, Cordeiro RLR. Reação cruzada no diagnóstico sorológico de leishmaniose canina. Rev Bras Parasitol Vet 2004; 13(S1): 238.

Gramiccia M, Gradoni L. The current status of zoonotic Leishmaniases and approaches to disease control. Int J Parasitol 2005; 35(11-12): 1169-1180. PMid:16162348. http://dx.doi.org/10.1016/j.ijpara.2005.07.001

Greca H, Silva AV, Langoni H. Associação entre a presença de anticorpos anti-Leishmania sp. e anti-Neospora caninum em cães de Bauru, SP. Arq Bras Med Vet Zootec 2010; 62(1): 224-227. http://dx.doi.org/10.1590/ S0102-09352010000100032

Guillén Llera JL, García MLL, Martín-Reinoso E, Vivar-González R. Differential serological testing by simultaneous indirect immunofluorescent antibody test in canine leishmaniosis and erlichiosis. Vet Parasitol 2002; 109(3-4): 185-190. http://dx.doi.org/10.1016/ S0304-4017(02)00306-0

Guimarães AM, Rocha CMBM, Oliveira TMFS, Rosado IR, Morais LG, Santos RRD. Fatores associados à soropositividade para Babesia, Toxoplasma, Neospora e Leishmania em cães atendidos em nove clínicas veterinárias do município de Lavras, MG. Rev Bras Parasitol Vet 2009; 18(S1): 49-53. PMid:20040191. http://dx.doi.org/10.4322/ rbpv.018e1009

Kuhls K, Alam MZ, Cupolillo E, Ferreira GEM, Mauricio IL, Oddone $\mathrm{R}$, et al. Comparative microsatellite typing of new world Leishmania infantum reveals low heterogeneity among populations and its recent old world origin. PLoS Negl Trop Dis 2011; 5(6): e1155. Epud 2011 Jun 7.

Labruna MB, Pereira MC. Carrapatos em cães no Brasil. Clin Vet 2001; 30(6): 24-32.

Lobetti RG. Canine Babesiosis. Compendium on Continuing Education for the Practicing Veterinarian 1998; 20(4): 418-430.

Lopes MG, Mendonça IL, Fortes KP, Amaku M, Pena HFJ, Gennari SM. Presence of antibodies against Toxoplasma gondii, Neospora caninum and Leishmania infantum in dogs from Piauí. Rev Bras Parasitol Vet 2011; 20(2): 111-114. PMid:21722484. http://dx.doi.org/10.1590/ S1984-29612011000200004

Noronha Junior CF, Assis J, Dobre PR, Queiroz NMGP, Silveira RCV, Starke-Buzetti WA, et al. Leishmaniose Visceral Canina (LVC) em cães do município de Ilha Solteira, SP, Brasil. Ciên Agr Saúde FEA 2007; 7(1): 32-367.
Oliveira TMFS, Furuta PI, Carvalho D, Machado RZ. A study of cross-reactivity in serum samples from dogs positive for Leishmania sp., Babesia canis and Ehrlichia canis in enzyme -linked immunosorbent assay and indirect fluorescent antibody test. Rev Bras Parasitol Vet 2008; 17(1) 7-11. PMid:18554433.

Paulan SC, Silva HR, Lima EACF, Flores EF, Tachibana VM, Kanda C, et al. Distribuição espacial da leishmaniose visceral canina em Ilha Solteira, São Paulo, Brasil. Eng Agríc 2012; 32(4): 765-774. http://dx.doi. org/10.1590/S0100-69162012000400016

Pinelli E, Kellick-Kendrick R, Wagenaar J, Bernadina W, Real G, Ruitenberg J. Cellular and humoral immune responses in dogs experimentally and naturally infected with Leishmania infantum. Infect Immun 1994; 62(1): 229-235. PMid:8262632 PMCid:186091.

Porrozzi R, Pereira MS, Teva A, Volpini AC, Pinto MA, Marchevsky RS, et al. Leishmania infantum-induced primary and challenge infections in rhesus monkeys (Macaca mulatta): a primate model for visceral leishmaniasis. Trans R Soc Trop Med Hyg 2006; 100(10): 926-937. PMid:16455120. http://dx.doi.org/10.1016/j.trstmh.2005.11.005

Queiroz NMGP, Assis J, Oliveira TMFS, Machado RZ, Nunes CM, Starke-Buzetti WA. Diagnóstico da leishmaniose Visceral Canina pelas técnicas de imunoistoquímica e PCR em tecidos cutâneos e associação com a RIFI e ELISA-teste. Rev Bras Parasitol Vet 2010; 19(1): 32-38. PMid:20385057. http://dx.doi.org/10.4322/rbpv.01901006

Ribeiro RR, Silva ME, Silva SM, Fulgêncio GO, Pena HFJ, Frézard F, et al. Occurrence of anti-Neospora caninum and anti-Toxoplasma gondii antibodies in dogs with visceral leishmaniasis. Pesq Vet Bras 2011; 31(6): 527-532. http://dx.doi.org/10.1590/ S0100-736X2011000600012

Ross R. Further notes on Leishman's bodies. Br Med J1903; 2(2239): 1401. PMid:20761210 PMCid:2514909. http://dx.doi.org/10.1136/ bmj.2.2239.1401

Souza SLP, Gennari SM, Yai LEO, D’Auria SRN, Cardoso SMS, Guimarães Junior J, et al. Occurrence of Toxoplasma gondii antibodies in sera from dogs of the urban and rural areas from Brazil. Rev Bras Parasitol Vet 2003; 12(1): 1-3.

Souza SLP, Guimarães Junior JS, Ferreira F, Dubey JP, Gennari SM. Prevalence of Neospora caninum antibodies in dogs from dairy cattle farms in Parana, Brazil. J Parasitol 2002; 88(2): 408-409. PMid:12054023.

Tarantino C, Rossi G, Kramer LH, Perrucci S, Cringoli G, Macchioni G. Leishmania infantum and Neospora caninum simultaneous skin infection in a young dog in Italy. Vet Parasitol 2001; 102(1-2): 77-83. http://dx.doi. org/10.1016/S0304-4017(01)00518-0 